UDC 661.665.2-033.24:669.27

\author{
C. Liu' ${ }^{1}$, N. Lin ${ }^{1,2,{ }^{*}, \text { Y. H. He }}{ }^{1}$, W. S. Liu ${ }^{1}$, Y. Z. Ma ${ }^{1}$ \\ ${ }^{1}$ State Key Laboratory for Powder Metallurgy, \\ Central South University, Changsha, China \\ ${ }^{2}$ School of Materials Science and Engineering, Hunan University, \\ Changsha, China \\ *linnan@csu.edu.cn
}

\title{
Influence of micron WC addition on the microstructure and mechanical properties of ultrafine WC-Co cemented carbides at the elevated temperature
}

In this paper, the influence of micron-grained WC additions with the different grain sizes on the microstructure and hardness of ultrafine WC-Co cemented carbides at the elevated temperature were investigated by the scanning electron microscope and mechanical properties test. The Vickers hardness and transverse rupture strength of hardmetals were measured at temperatures ranging from room temperature to $800^{\circ} \mathrm{C}$. The results show that the addition of micron-sized WC particles can lead to the increase of fracture toughness and slow the decreasing of hardness at the elevated temperature.

Keywords: $W C-C o$, microstructure, transverse rupture strength, high temperature hardness, fracture toughness.

\section{INTRODUCTION}

Cemented carbides have been widely used as cutting, mining, and drilling tools, as well as wear-resistant parts, due to their extremely high hardness, excellent toughness and wear resistance $[1,2]$. Compared to the traditional micron grained WC-Co materials, the ultrafine grained WC-Co hardmetals with the submicron or nano-WC grain size can improve the hardness, strength and wear resistance of cemented carbides obviously $[3,4]$. Therefore, the control and refining of $\mathrm{WC}$ grain on the ultrafine-grained or nano-crystalline $\mathrm{WC}-\mathrm{Co}$ cemented carbides have been investigated for many years [5].

The tungsten carbide cermet is a typical cutting tool, because of the perfected red hardness above the desired temperatures, and it is used as the high speed machining requires superior cutter materials. However, the microstructure evolution and WC grain sized characteristics of cemented carbides can bring about the decreasing hardness of sintered specimens with the increasing temperature $[6,7]$. In addition, with increasing temperature from 600 to $800^{\circ} \mathrm{C}$, the hardness of $\mathrm{WC}$ 10Co (mean grain size $0.78 \mu \mathrm{m}$ ) can decrease clearly by 31 percent [8]. The decreasing of hardness may damage wear resistant of the cutting tools.

In our previous research, through the addition of $\mathrm{Cu}$ in $\mathrm{WC}-\mathrm{Co}$ cemented carbides, and the growth of finer WC particles and the dissolution of WC hard phase can be inhibited effectively at elevated temperature. Moreover, $\mathrm{WC}-\mathrm{Co}-\mathrm{Cu}$ cemented carbides exhibit the higher hardness at elevated temperature [8]. In this paper, we developed a method to rapidly prepare a $\mathrm{WC}-\mathrm{Co}$ composite powders 
which have the specific particle size distribution, and fabricated the cemented carbides with the different WC grain size distribution.

\section{EXPERIMENTAL SECTION}

The sizes of different $\mathrm{WC}$ are $0.2,1,2$ and $3 \mu \mathrm{m}$, and the size of Co is $0.8 \mu \mathrm{m}$, respectively. The related parameters of experimental raw powders are shown in Table 1. The nominal composition of the cemented carbides in this work is given in Table 2, the $0.4 \mathrm{wt} \% \mathrm{VC}$ and $0.4 \mathrm{wt} \% \mathrm{Cr}_{3} \mathrm{C}_{2}$ as the grain growth inhibitors were added to these alloys. The mixtures were prepared through the ball milling in anhydrous alcohol for $24 \mathrm{~h}$ at the milling speed of $300 \mathrm{r} / \mathrm{min}$ and the ball-topowder is 2:1. After the ball milling, the composite powders were dried in a vacuum oven at $90^{\circ} \mathrm{C}$ for $4 \mathrm{~h}$. At the same time, the powders were mixed with paraffins as the formative agent. The two action pressure was adopted to make green compacts at $200 \mathrm{MPa}$. The green compacts were sintered at $1400{ }^{\circ} \mathrm{C}$ for $60 \mathrm{~min}$, the pressure during the whole final temperature sintering process was $5 \mathrm{MPa}$ in an argon atmosphere to avoid the prominent evaporation of the cobalt during the liquid phase sintering. After sintering, the alloys were cooled to the room temperature at a rate of $25{ }^{\circ} \mathrm{C} / \mathrm{min}$ in the vacuum sintering furnace. The alloy samples having the dimension of $30 \times 5 \times 5 \mathrm{~mm}$ were prepared for microstructural analysis and mechanical properties measurement.

Table 1. Related parameters of experimental WC powders

\begin{tabular}{cccccccc}
\hline Power grade & Fsss, $\mu \mathrm{m}$ & Scott density, $\mathrm{g} \cdot \mathrm{in}^{-3}$ & $\mathrm{Ct}, \%$ & $\mathrm{Cc}, \%$ & Oxygen, $\%$ \\
\hline GWC002 & - & 45.94 & 6.13 & 6.10 & 0.30 \\
GWC010 & 1.04 & 45.33 & 6.14 & 6.11 & 0.038 \\
GWC020 & 2.07 & 44.09 & 6.14 & 6.12 & 0.042 \\
GWC030 & 3.04 & 57.32 & 6.13 & 6.11 & 0.031 \\
GcoB-008 & 0.84 & 8.19 & 0.0199 & - & 0.41 \\
\hline
\end{tabular}

Table 2. Nominal composition of specimens powders (mass fraction, \%)

\begin{tabular}{c|c|c|c|c|c|c}
\hline $\begin{array}{c}\text { Sample } \\
\text { number }\end{array}$ & $\begin{array}{c}\text { WC-0.2, } \\
\mu \mathrm{m}\end{array}$ & $\begin{array}{c}\text { WC-1, } \\
\mu \mathrm{m}\end{array}$ & $\begin{array}{c}\text { WC-2, } \\
\mu \mathrm{m}\end{array}$ & $\begin{array}{c}\text { WC-3, } \\
\mu \mathrm{m}\end{array}$ & $\begin{array}{c}\text { Co-0.8, } \\
\mu \mathrm{m}\end{array}$ & $\begin{array}{c}\text { Carbon } \\
\text { black }\end{array}$ \\
\hline Alloy 1 & Balance & - & - & - & 8 & 0.2 \\
Alloy 2 & Balance & 20 & - & - & 8 & 0.2 \\
Alloy 3 & Balance & - & 20 & - & 8 & 0.2 \\
Alloy 4 & Balance & - & - & 20 & 8 & 0.2 \\
\hline
\end{tabular}

The density of the sintered alloys was measured by Archimedes method. The microstructure of polished specimens was studied using an FEI Nano230 SEM equipped with energy dispersive spectroscopy (EDS). The X-ray diffraction (XRD) analysis was carried out for phase identification [9-11]. The transverse rupture strength was tested by the 3-point bending method with an INSTRON3369. The hardness of all specimens were measured with an indenting load of $3 \mathrm{~kg}$ by HTVPHS30 at room temperature, $200,400,600$, and $800{ }^{\circ} \mathrm{C}$ after holding 10 min in the Ar atmosphere, respectively.

\section{RESULTS AND DISCUSSION}

It can be seen from Fig. 1 that the microstructure of WC-Co cemented carbides with the various sized WC grains was observed using BSE mode in the SEM. 
Figure 2 showed the grain size distributions of $\mathrm{WC}-\mathrm{Co}$ cemented carbides samples. The addition of micron-sized WC powders can influence the WC particles size variation obviously. From the Fig. 1, $a$, the alloy has the ultrafine grained WC without the micro-sized WC powders addition. Due to the existence of grain growth inhibitor in composite powders, the abnormal growth of WC particles are not found in the alloy 1 at the final sintering temperature. From Figs. 1, $b$ and 2, with the addition of different coarse grain-sized WC powders, the hardmetals possessed the microstructure with the micron grained WC and ultrafine grained WC synchronously.
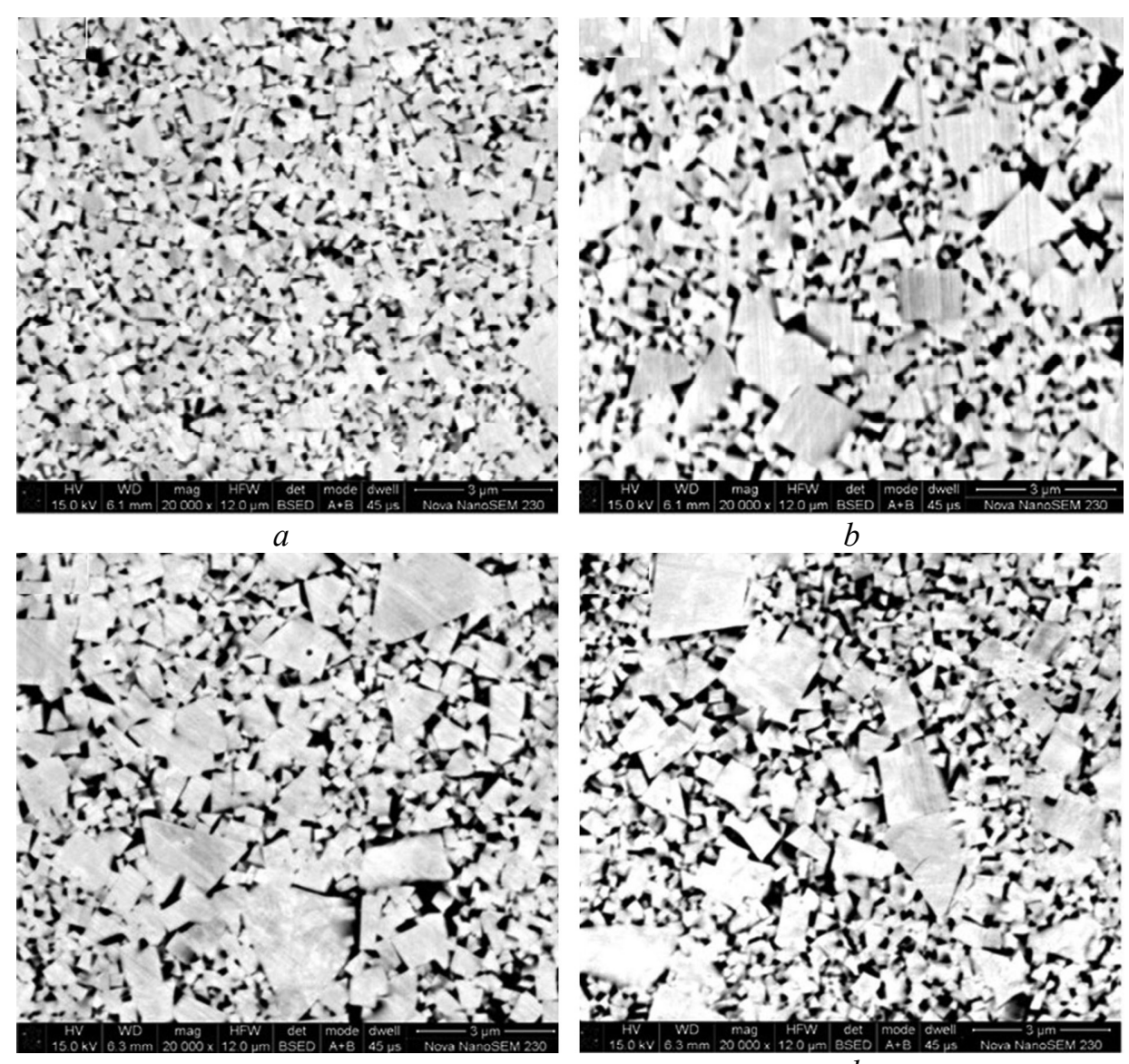

Fig. 1. SEM microstructure of sintered hard metal samples, alloy $1(a), 2(b), 3(c), 4(d)$.

The variations of the relative density of the sintered alloys were studied by the Archimedes method. It can be seen from Table 3 that the highest density can be obtained for the specimens with the free micron-sized WC (absolute density of $\left.14.67 \mathrm{~g} / \mathrm{cm}^{3}\right)$. With the addition of different micro-sized WC $(1,2$ and $3 \mu \mathrm{m})$ in WC-Co cemented carbides, the density decreases from 14.63 to $14.51 \mathrm{~g} / \mathrm{cm}^{3}$, respectively. This phenomenon can be explained by the sintering mechanism of WC-Co tungsten carbide, which is mainly depending on the WC particle rearrangement and dissolution-precipitation process. WC particles in the liquid phase can appear the displacement phenomenon with the surface tension driving, the capillary force and viscous flow of liquid phase, which can result in the position adjustment and rearrangement of WC particle [5]. The existence of micron-sized 
WC can impede the ultrafine WC particle rearrangement in the liquid phase, which means that the most closely arranged WC grains can hardly be achieved. In the WC dissolution process, the higher dissolution rate of ultrafine grained WC in liquid phase sintering process can achieve the excellent substance migration result and obtain the complete densification microstructure. However, the micron-sized WC with slower dissolution velocity can inhibit the densification process through the dissolution and precipitation of WC grains [12-14].
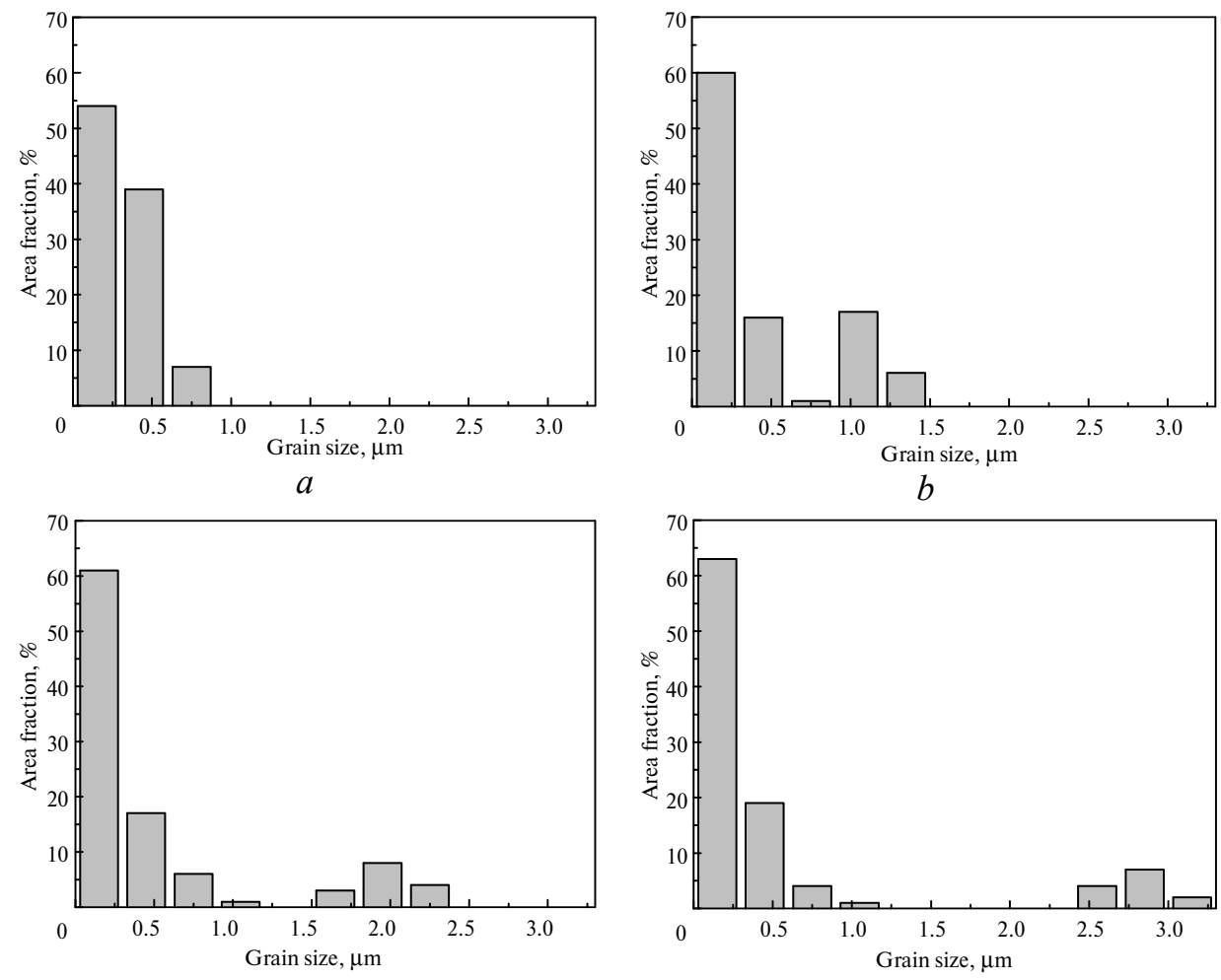

$c$

$d$

Fig. 2. Grain size distributions of sintered hard metal samples: alloy $1(a), 2(b), 3(c), 4(d)$.

Table 3. Comparison of the properties of the various alloys

\begin{tabular}{c|cccc}
\hline Specimen No & 1 & 2 & 3 & 4 \\
\cline { 1 - 1 } Absolute density, \% & 14.67 & 14.63 & 14.59 & 14.51 \\
\cline { 1 - 1 } Hardness $H V$ & 1950 & 1750 & 1700 & 1600 \\
\cline { 1 - 1 } Fracture toughness, MPa.m $^{1 / 2}$ & 12.8 & 14.9 & 15.9 & 16.8 \\
\hline
\end{tabular}

In order to investigate the effect of micro-sized $\mathrm{WC}$ addition on the phases of cemented carbides, XRD analysis was performed as shown in Fig. 3. It can be seen from Fig. 3 that the cemented carbides with different micron-sized WC addition can possess the diffraction peaks of WC and f.c.c. Co phases. Table 3 shows that the micron-sized WC addition can improve the fracture toughness properties of cemented carbides obviously. However, previous investigations can indicate that the Co phase structure can play an important role in the strength and toughness of cemented carbide. Owing to the fact that f.c.c. Co can have more sliding systems 
than h.c.p. Co, the dislocations in f.c.c. Co are easier to slide under external force, which can bring about the excellent toughness of WC-Co cemented carbides [1517].

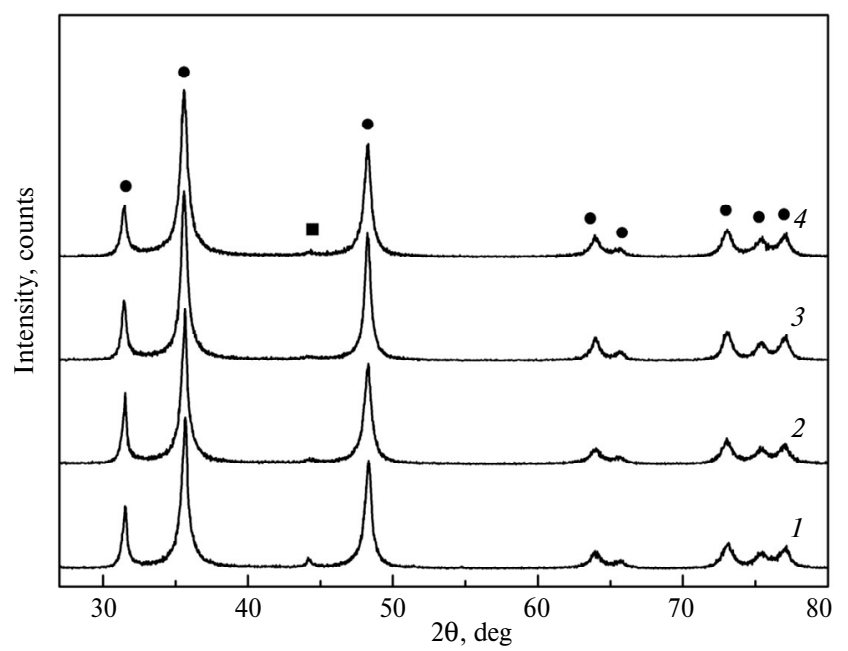

Fig. 3. XRD patterns of the sintered hard metal samples: alloy 1 (1), 2 (2), 3 (3), 4 (4), WC (•), f.c.c. Co (ם).

Figure 4 shows the effects of different temperature on the transverse rupture strength of ultrafine $\mathrm{WC}-($ micron $\mathrm{WC}-\mathrm{Co})$ cemented carbides. When the binder has the same weight ratio, the WC-Co cemented carbides can significantly increase the strength of the samples at all test temperatures. This phenomenon can be explained that the average WC grain size of ultrafine WC-(micron WC-Co) alloys, as shown in Fig. 5. Compared with Fig. 1, $a$, increasing the grain-size of micron WC can obviously increase strength of alloys at the same temperature, and the WC grain size of alloys can increase clearly at the test temperature increase from room temperature to $800^{\circ} \mathrm{C}$.

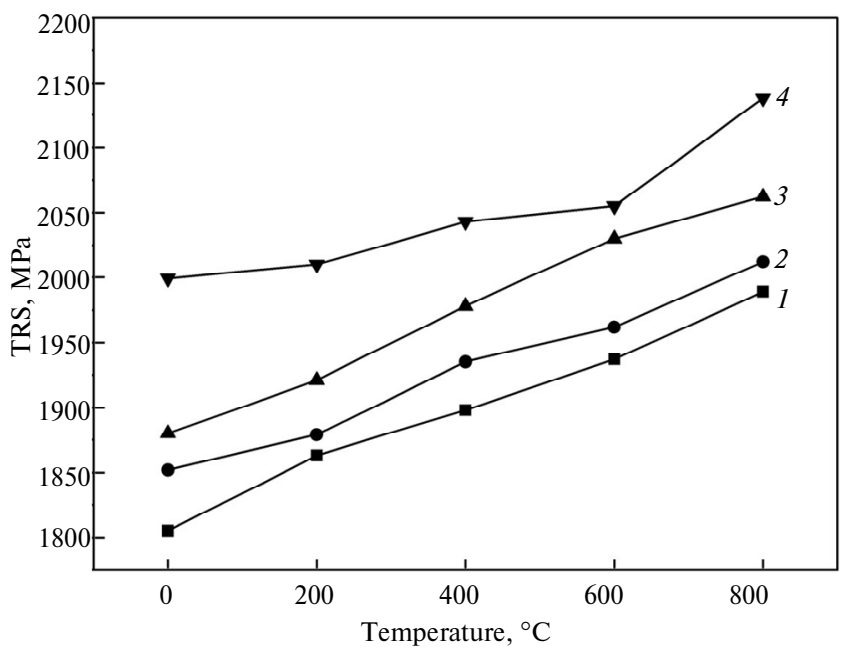

Fig. 4. The transverse rupture strength of the $\mathrm{WC}-8 \mathrm{Co}$ cemented carbides at the various temperature: alloy 1 (1), 2 (2), 3 (3), 4 (4). 


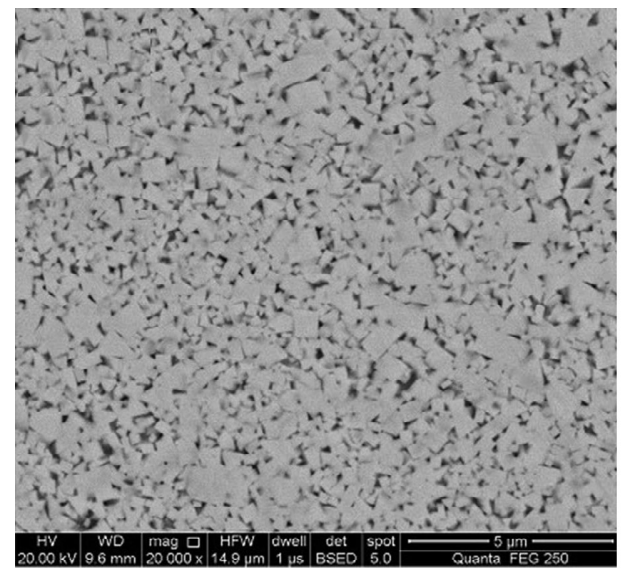

$a$

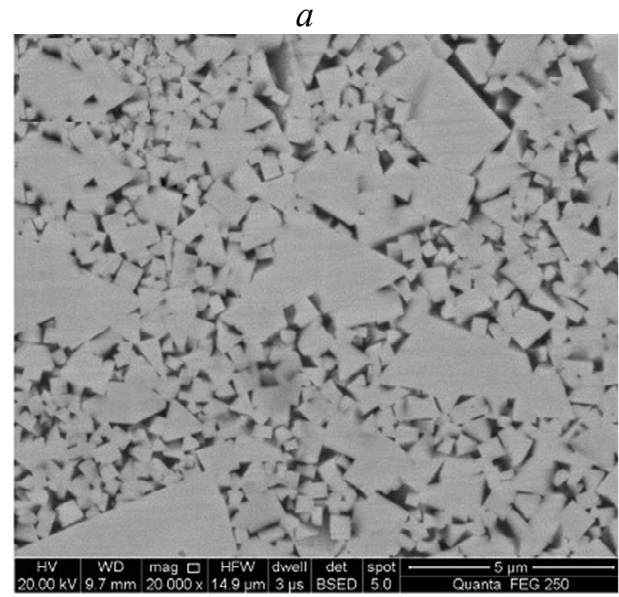

$c$

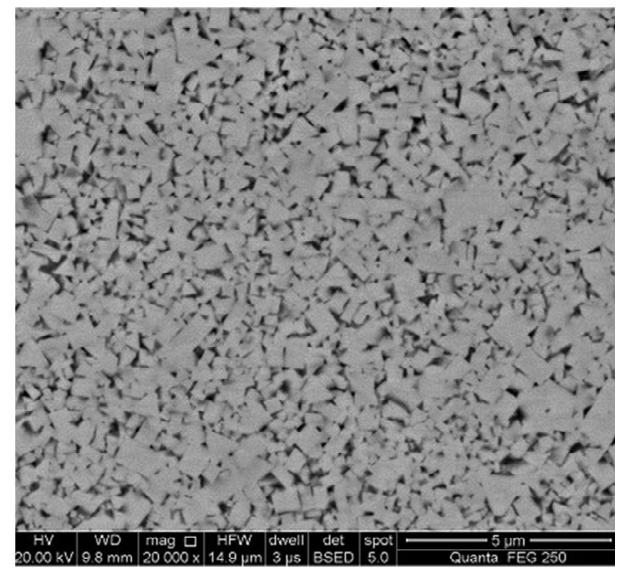

$b$

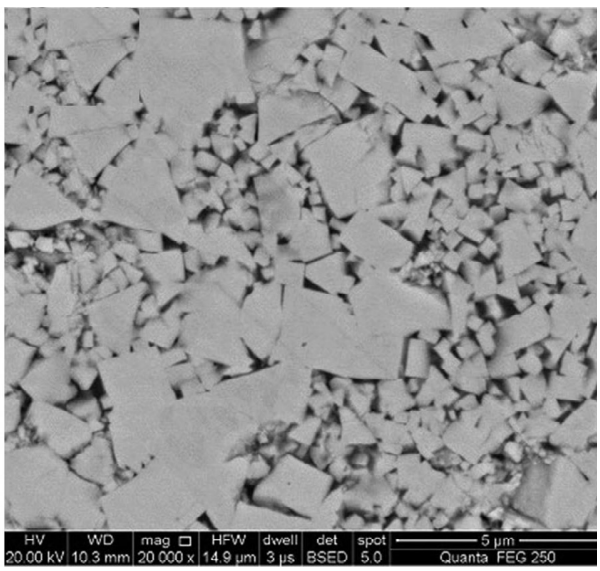

$d$

Fig. 5. The SEM-BSE microstructure of hard metal samples after tested at elevated temperature, alloy 1 after tested at $600(a)$ and $800{ }^{\circ} \mathrm{C}(b)$, alloy 4 after tested at $600(c)$ and $800{ }^{\circ} \mathrm{C}(a)$.

The Fig. 6 shows that the Vickers hardness values of ultrafine WC-(micron WC-Co) cemented carbides at the different test temperatures. We can find that the hardness of WC-Co cemented carbides with different micron WC powders addition can significantly decrease at the high temperature. Moreover, increasing the grain-size of micron WC particles can obviously decrease the hardness of WC-Co hardmetals with the increasing temperature. Compared with the WC-10Co cemented carbides, the alloy 1 almost can increase 29 percent more than that, although alloy 4 may show similar hardness values from room to $200{ }^{\circ} \mathrm{C}$, and every specimens have higher hardness values at $800^{\circ} \mathrm{C}$ [8]. From the Fig. 6, we can see that the addition of micro-sized WC takes a positive effect on the hardness of WCCo cemented carbides at high temperature.

To explore the mechanism of hardness of the WC-Co cemented carbides at the high temperature in this research, the microstructure of WC-Co hardmetals with micro-sized WC addition tested in different temperature can be shown in Fig. 6 . Compared with the Fig. 1, the WC grain size of can increase obviously with the increasing test temperature. However, the WC grain size of ultrafine WC-(micron WC-Co) alloys can increase more obvious than that of WC-Co without the micron WC powders addition, as shown in Fig. $1, b$ and Fig. 5, $b, d$. Especially, the largest WC grain size of ultrafine $\mathrm{WC}-($ micron $\mathrm{WC}-\mathrm{Co}$ ) alloys increase form 3.1 to $4.7 \mu \mathrm{m}$ after tested at $800^{\circ} \mathrm{C}$, but the free micron WC alloy increases 0.5 to 
$0.6 \mu \mathrm{m}$. The growth of WC phase is tightly controlled within the binder phase through the $\mathrm{W}$ and $\mathrm{C}$ element diffusion process at the high temperature. It is shown that the addition of micron-sized WC powder can inhibit the redistribution and arrangement of WC powder in a liquid phase, and the WC grain growth is easier than free micron-sized WC alloy. This phenomenon can change the solid diffusion of $\mathrm{WC}$ in the binder phase and produce the new microstructure of hardmetals at elevated temperature.

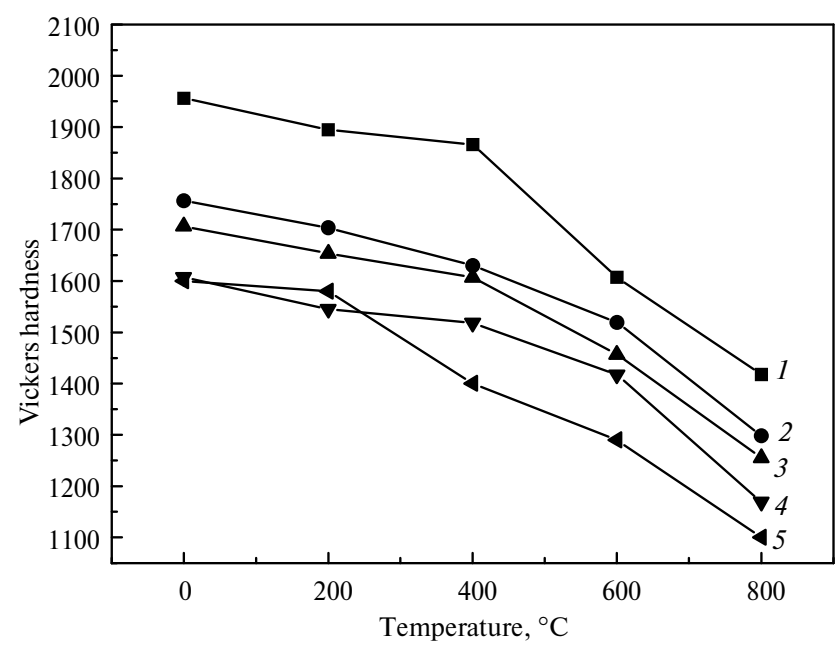

Fig. 6. The Vickers hardness values of the $\mathrm{WC}-8 \mathrm{Co}$ cemented carbides at the various temperature: alloy 1 (1), 2 (2), 3 (3), 4 (4), WC-19Co [8] (5).

In the high speed machining technology, the high hardness of cemented carbide at approximately $800{ }^{\circ} \mathrm{C}$ is required. The WC particles can diffuse and dissolve into the binder phase, and this behavior can affect the microstructural stability. Moreover, the hardness of WC-Co cemented carbides can depend on the coarsening proportion of $\mathrm{WC}$ grain size, WC hard phase and binder phases at elevated temperature. Compared with the ultrafine $\mathrm{WC}-\mathrm{Co}$ cemented carbides, and the addition of micron-sized WC powder may significantly inhibit the decreasing of hardness in cemented carbides at elevated temperature. It can be seen from Fig. 6, the hardness of different samples are decrease by increasing the tested temperature.

\section{CONCLUSIONS}

In this paper, the effects of different micron-sized WC additions on the microstructure and hardness of WC-Co cemented carbide have been investigated. The addition of micron-sized WC particles can lead to the decrease in the absolute densities and mechanical properties of cemented carbide, and the strength of alloys are increase by the increasing tested temperature, and the hardness of different samples are decrease by the increasing tested temperature. The synthesis of ultrafine $\mathrm{WC}-($ micron $\mathrm{WC}-\mathrm{Co})$ hardmetals can be suitable for the production of high-quality $\mathrm{WC}-\mathrm{Co}$ cemented carbides, and provide a novel method to improve the lifetime of $\mathrm{WC}-\mathrm{Co}$ tools in the cutting process.

\section{ACKNOWLEDGMENTS}

This work is supported by the Key State Science and Technology Projects of China (2012ZX04003-021). 
Досліджено вплив добавок WC з зернами різних мікронних розмірів на мікроструктуру і твердість надтвердого WC-Со-сплаву при підвищеній температурі за допомогою скануючого електронного мікроскопу і проведено випробування його механічних властивостей. Твердість за Віккерсом і поперечну міџність на розрив твердих металів вимірювали у діапазоні від кімнатної температури до $800{ }^{\circ} \mathrm{C}$. Результати показали, щзо добавка WC-частинок мікронних розмірів може призвести до збільшення тріщиностійкості і уповільнити зменшення твердості при підвищеній температурі.

Ключові слова: $W C-C о$, мікроструктура, спротив поперечному розриву, високотемпературна твердість, тріщиностійкість.

Исследовано влияние добавок WC с зернами различных микронных размеров на микроструктуру и твердость сверхтвердого WC-Со-сплава при повышенной температуре с помощью сканирующего электронного микроскопа и проведено испьтание его механических свойств. Твердость по Виккерсу и поперечную прочность на разрыв твердых металлов измеряли в диапазоне от комнатной температуры до $800{ }^{\circ} \mathrm{C}$. Результаты показали, что добавка WC-частии микронных размеров может привести к увеличению трещиностойкости и замедлить уменьшение твердости при повышенной темпеpamype.

Ключевые слова: $W C-C o$, микроструктура, сопротивление поперечному разрыву, твердость при высокой температуре, трещиностойкость.

1. Chen H. S., Feng K. Q., Xiong J., Luo J. J., Guo Z. X., Wang H. Characterization and forming process of a functionally graded $\mathrm{WC}-\mathrm{Co} / \mathrm{Ni}$ composite // Int. J. Refract Met. Hard Mater. 2012. - 35. - P. 306-310.

2. Lin N., Jiang Y., Zhang D. F., Wu C. H., He Y. H., Xiao D. H. Effect of Cu, Ni on the property and microstructure of ultrafine WC-10Co alloys by sinter-hipping // Ibid. - 2011. - 29. P. 509-515.

3. Fang Z. Z, Wang X., Ryu T., Hwanga K. S., Sohn H. Y. Synthesis, sintering, and mechanical properties of nanocrystalline cemented tungsten carbide, a review // Ibid. - 2009. - 27. P. 288-99.

4. Ou X. Q., Xiao D.H., Shen T. T., Song M., He Y. H. Characterization and preparation of ultrafine grained WC-Co alloys with minor La-additions // Ibid. - 2012. - 31. - P. 266-273.

5. Liu C., Lin N., He Y. H., Wu C. H., Jiang Y. The effects of micron WC contents on the microstructure and mechanical properties of ultrafine $\mathrm{WC}-($ micron $\mathrm{WC}-\mathrm{Co}$ ) cemented carbides // J. Alloys Comp. - 2014. - 594. - P. 76-81.

6. Jia K., Fischer T. E., Gallois B. Microstructure, hardness and toughness of nanostructured and conventional WC-Co composites // Nanostruct Mater. - 1998. - 10. - P. 875-891.

7. Milman Y. V., Luyckx S., Northrop I. T. Influence of temperature, grain size and cobalt content on the hardness of WC-Co alloys // Int. J. Refract Met. Hard Mater. - 1999. - 17. - P. 39-44.

8. Lin N., He Y. H., Wu C. H., Jiang Y. Influence of copper content on the microstructure and hardness of copper-doped tungsten carbide-cobalt bulk at the elevated temperature // Ibid. 2013. - 38. - P. 140-143

9. Xiao D. H., He Y. H., Song M., Lin N., Zhang D. F. $\mathrm{Y}_{2} \mathrm{O}_{3^{-}}$and $\mathrm{NbC}$-doped ultrafine WC-10Co alloys by low pressure sintering // Ibid. - 2010. - 28. - P. 407-411.

10. Milman Y. V., Luyckx S., Goncharuck V. A., Northrop J. T. Results from bending tests on submicron and micron WC-Co grades at elevated temperatures // Ibid. - 2002. - 20, N 1. P. 71-79.

11. Shen T. T., Xiao D. H., Ou X. Q., Song M., He Y. H., Lin N., Zhang D. F. Effects of LaB 6 addition on the microstructure and mechanical properties of ultrafine grained $\mathrm{WC}-10 \mathrm{Co}$ alloys // J. Alloys Comp. - 2011. - 509. - P. 1236-1243.

12. Xu C. H., Ai X., Huang C. Z. Research and development of rare-earth cemented carbides // Int. J. Refract Met. Hard Mater. - 2001. - 19. - P. 159-168.

13. Xiong J., Yang J. G., Guo X. H. Application of rare earth elements in cemented carbideinserts drawing dies and mining tools // Mater. Sci. Eng. A. - 1996. - 209. - P. 287-293.

14. Milman Y., Luyckx S., Northrop J. T. I. Influence of temperature, grain size and cobalt content on the hardness of WC-Co alloys // Int. J. Refract Met. Hard Mater. - 1999. - 17. P. 39-44. 
15. Konyashin I., Hlawatschek S., Ries B., Lachmann F., Dorn F. On the mechanism of WC coarsening in WC-Co hardmetals with various carbon contents // Ibid. - 2009. - 27. - P. 234 243.

16. Tamara A. F., Željko A., Danko Ć. Influence of consolidation process and sintering temperature on microstructure and mechanical properties of near nano- and nano-structured WC-Co cemented carbides // Ibid. - 2016. - 54. - P. 82-89.

17. Yang Q., Senda T., Hirose A. Sliding wear behavior of WC-12\% Co coatings at elevated temperatures // Surf. Coat. Tech. - 2006. - 200. - P. 4208-4212.

Received 17.08.16 